\title{
Application of indigenous Language (IGBO) for Improving the Teaching of Vocational Agriculture at the Junior Secondary Schools in Ebonyi State, Nigeria
}

\author{
Ndem, J. U. ${ }^{1} \quad$ Nwigwe, $\mathrm{N}^{2} \quad$ EzeJ. N. ${ }^{2}$ \\ 1.Department of Technology and Vocational Education, Faculty of Education, Ebonyi State University \\ 2.Department of Arts and Social Science Education, Faculty of Education, Ebonyi State University, Abakaliki
}

\begin{abstract}
This study was aimed at determining the application of indigenous language (Igbo) for improving teaching of Vocational Agriculture at the Junior Secondary Schools. Four research questions and one null hypothesis guided the study. The design of the study was descriptive survey research design and the population of the study was two hundred and seventy six (276) teachers comprised (140 Igbo language teachers and 136 Vocational Agriculture teachers. There was no sampling, as the entire population was used for the study. A questionnaire designed by the researchers was used to collect data. The data analysis was done using mean, standard deviation and t-test was used to test the hypothesis. The results of the study indicated that the indigenous language (Igbo) could be used to teach vocational agriculture at the Junior Secondary Schools. Based on the findings, it was recommended that vocational agriculture teachers should use their local or indigenous language (Igbo) in teaching and learning of vocational agriculture at the Junior Secondary School level. Government and all the authorities concerned in Junior Secondary School administration should ensure that teachers' manuals and hand books in vocational agriculture are fully translated in Igbo language for effective teaching and learning.
\end{abstract}

Keywords: Indigenous Language; Igbo; Teaching; Vocational; Agriculture; Junior Secondary.

DOI: $10.7176 / \mathrm{JEP} / 11-36-03$

Publication date: December $31^{\text {st }} 2020$

\section{Introduction}

The importance of language in communication is so great that no meaningful progress in inter personal relations could be made without it. Language makes human society possible. Without language, society and culture may not exist. Language provides the means of communication and interaction between individuals and between groups. It is also the means by which individuals and groups of individuals cooperate and live together in a society. Language are of different types. It may be classified into foreign and indigenous.

The indigenous language which is also known as the mother tongue has been defined as the language which a group of people considered to be the inhabitants of an area, acquire in their early years and which normally becomes their mutual instrument of thought and communication (OhiriAniche, 2014). The idea of the mother tongue therefore, is that it is the language one first hear and learn to use, literally at one's mother's breast, or in the very bossom of the family. Since it is the language one first acquires, the mother tongue is also referred to as the person's first language or $\mathrm{L}_{1}$.

Nigeria is a multilingual and multiethnic society with over five hundred (500) indigenous languages spoken within her borders (Blench, 2012). Three (3) of these indigenous languages are considered to be major. They are; Igbo, Hausa and Yoruba (Federal Republic of Nigeria, 1998; 2013). Others includes; Fulfulde, Kanuri, Ibibio, Tiv, Ijaw, Edo Annang, Nupe, Urhobo, Igala, Efik, Idom, Isoko, Birom, Ogoni and others. The indigenous language being considered in this work is Igbo Language.

Igbo language is one of the major indigenous languages in Nigeria that is spoken by over 16 million people in the South East Nigeria (FRN, 2007). Igbo language is the supreme expression of the cultural heritage of the people of South East Nigeria. Without Igbo language, it would be difficult to talk about cultural revival, research, teaching and learning of Igbo in School or in the world. It is the language of tradition and cultural communication in the markets, farms, village meetings and day to day transactions outside or within the offices, in the churches, public gathering, and in Igbo Social and political arena. It is the language in which any Igbo child is expected to speak, think and even express his/her feelings and emotions. The attempt to ignore this familiar language in teaching and learning especially among Igbo speaking environment is like taking learner away from home and putting him among strangers.

According to UNESCO (1974) children learn better and faster-eagerly-when instructed in their mother tongue. They further recommended that the most effective means of teaching any child was the mother tongue. Most countries that have advanced scientifically and technologically harness the full potential of science and technology through the use of their indigenous languages,countries like, China, India, Germany, Japan etc. The case is different in most of the third world countries, Nigeria inclusive, as mother tongue is relegated to the background and seen as language of the illiterate rural dwellers. 
According to Bamgbose (1984) Pupils learn better in their mother tongue or language of the immediate community. Owolabi and Makinde (2008:229) observed that most African countries that use English as their second language as a medium of instruction in their schools are increasingly becoming aware of the effect of language deficiency on the performance of their students in science and mathematics. Otuka (1998:11) said that a large proportion of the pupils listening to science, technology and mathematics lesson given in a non-mother tongue would miss a great deal of the lesson done due to difficulty in understanding of the language rather than the scientific content. Olarewaju (1999) have stressed the fact that students achieve more in science when taught in their indigenous language or language of the immediate environment.

Collier and Thomas (2004) and Garcia(2005) have commented on the negative results of forcing second language $\left(\mathrm{L}_{2}\right)$ as the medium of instruction for students from an $\mathrm{L}_{1}$ background. They found that students who study in school with non-native language cannot fully develop their language skills in either languages and this leads to problems in their academic success, continuing education and future career success in sciences, arts, and other subject areas especially vocational agriculture.

Vocational agriculture is the field of study in Agriculture that trains the learners on skills in agricultural production, processing of agricultural commodities, marketing of the commodities and soil conservation in the environment. Vocational agriculture is part of general education offered at the primary and junior secondary schools in Nigeria.Ndem (2016) conceptualized vocational agriculture as the aspect of vocational education including general education which trains the learners on skills, competencies, values, norms, habits, and citizenship required in agricultural production. He further explained that vocational agriculture is given at the primary and Junior Secondary Schools aimed at developing interest in agricultural production among the youths. He further explained that the general objectives of vocational agriculture at the primary school are (i) to acquire basic skills relevant to agriculture (ii) To acquaint the pupils the basic scientific principles and procedures (iii) To ensure that pupils apply the basic scientific principles and procedures to agricultural problems (iv) To develop attitudes in the pupils to accept the need for change and adaptation. (v) Develop the attitude in the pupils for self-confidence necessary to survive in a changing environment. (vi) Develop the attitude and motivation to participate actively in the improvement of their environment. (vii) Develop the social skills and attitudes necessary for co-operation with other members of the community and nation.

Furthermore, the pupils are expected to have the knowledge of parts of a plant, life cycle of plants, crops and their requirements, mode of propagation of crops, diseases and pests of crops, crop improvement as well as sources of improved planting materials, common tools used in agricultural production as well as the skills in weed controls, diseases and pest control, application of manure on crops, maintenance of soil fertility, handling common farm tools and techniques of harvesting, processing and distribution of farm products.

Vocational Agriculture is taught at the Junior Secondary Schools.In Nigeria context. Junior Secondary School is the level of Education after the primary school level. The teaching of vocational agriculture is being carried out by Agricultural Science teachers. The agricultural science teachers are trained experts in agricultural production with theory and practical experiences.

Teaching could be defined as a process of educating someone (Akande, 2004). In other words, teaching is a process of developing the cognitive, affective and psychomotor powers of the learner through giving the learner knowledge of fact about one subject matter, reinforcing or developing positive attitude in the learner and also developing in the learner certain physical or manipulative skills. The teaching of vocational agriculture at the secondary school using the second language of the students has contributed to poor performance of the students and lack of interest in agricultural production among the youth in Igbo speaking environment in Nigeria.

\section{Statement of the Problem}

In teaching of Vocational Agriculture, many language can be used to impact knowledge and basic skills to the students. An indigenous language (Igbo) is one of those languages a teacher can use to impact knowledge and skills in Vocational Agriculture. Some of the students at the JSS level find it difficult to understand and acquire these basic skills when instructed in a second language $\left(\mathrm{L}_{2}\right)$. For instance, students experience difficulty in understanding the botanical names of crops, pests of animals and plants, weeds and diseases, as these were taught using their second language $\left(\mathrm{L}_{2}\right)$. These difficulties experienced by the students have resulted in the performance of an average students fallen below standard. This is a development that is attributable to poor performance of students in both internal and external examinations such as JSSCE and NECO in majority of schools in Ebonyi State. This study therefore was designed to investigate the application of indigenous language (Igbo) for improving the teaching of Vocational Agriculture at the Junior Secondary Schools in Ebonyi State, Nigeria.

\section{Purposes of the Study}

The main purpose of the study was to determine the application of indigenous language for teaching of Vocational Agriculture at the Junior Secondary Schools; specifically, the study sought to determine;

1. Application of indigenous language for teaching of the basic concepts in agriculture. 
2. Application of indigenous language for teaching of processes in agricultural production.

3. Application of indigenous language for teaching of protection of crops and animals in agricultural production.

4. Application of indigenous languages for teaching of agricultural business.

\section{Research Questions}

The following research questions were answered which guided the study.

1. How could indigenous language be applied for teaching of the basic concepts in agriculture?

2. How could the indigenous language be applied for teaching of processes in agricultural production?

3. How could the indigenous language be applied for teaching of crops and animals protection in agricultural production?

4. How could the indigenous language be applied for teaching of agricultural business?

\section{Hypothesis}

H01: There is no significant difference in the mean rating of the Igbo and Vocational Agriculture teachers on the use of indigenous language for teaching of vocational Agriculture at the Junior Secondary Schools.

\section{Methodology}

The study was limited to all the Junior Secondary Schools in Ebonyi State, Nigeria, and the descriptive survey research design was adopted in the study.

The population of the study was 276 teachers comprised of 136 Vocational agriculture teacher and 140 Igbo language teachers in the Junior Secondary Schools. (UBEB, 2020)

There was no sampling as the entire population was used for the study. The instrument for data collection was a researchers' constructed questionnaire designed in 4 - points rating scale, to elicit responses from the respondents. The response options were Strongly Agree (SA) 4 points, Agree (A) 3 points, Disagree (D) 2 points and Strongly Disagree (SD) 1 point.

The instrument was validated by three experts; one expert in Agricultural Education one expert in Igbo Language Education, and one expert in Measurement and Evaluation from Ebonyi State University. The reliability of the instrument was established using Pearson Product Moment Correlation (PPMC). The reliability coefficient of the instrument was found to be 0.86 . The score was high enough to consider the instrument suitable for the study. The copies of the questionnaire were administered to the respondents with the help of vice principal academic in each of the Junior Secondary Schools who served as research assistants

For data analysis, the research questions were answered using mean (x) and Standard Deviation (Sd). Items that scored 2.50 and above were deemed "Agreed or Strongly Agreed", while the items that scored below 2.50 were deemed "Disagreed or Strongly Disagreed". Null hypothesis was answered using t-test.

\section{Results}

Research Question 1: How could the indigenous language be applied in the teaching of the Basic concepts of Agriculture?

Table 1: Mean and Standard Deviation of the respondents on the application of indigenous language in teaching of basic concepts of Agriculture. $\quad \mathrm{N}=276$

\begin{tabular}{lllll}
\hline S/N & Items & $\overline{\boldsymbol{X}}$ & Sd & Decision \\
\hline 1 & Definition of Agriculture. & 3.21 & 0.93 & Agree \\
2. & Importance of Agriculture. & 3.29 & 0.87 & $*$ \\
3. & Forms of agriculture such as crop, farming, livestock farming, fishery and so & 3.20 & 0.82 & $*$ \\
& on. & & \\
4 & Different types of crops. & 3.18 & 0.78 & $*$ \\
5 & $\begin{array}{l}\text { Different types of farm animals such as poultry, aquatic animals, work animals, } \\
\text { guard animals etc }\end{array}$ & 3.24 & 0.82 & $*$ \\
\hline
\end{tabular}

Grand Mean $=\quad 3.22$

Key: * = Agree

Table 1 above revealed that all the items had their mean scores above the cut-off point of 2.50 . This shows that the respondents agreed that the basic concepts of agriculture could be taught by the use of indigenous language (Igbo), and the range of the standard deviation shows that the opinions of the respondents did not deviate far from the central mean.

Research Question 2: How would the indigenous language be used in teaching of the processes of Agricultural production? 
Table 2: Mean and Standard deviation of the respondents on the use of indigenous language in teaching of Agricultural production. $\quad \mathrm{N}=276$

\begin{tabular}{llccc}
\hline S/N & Items & $\overline{\boldsymbol{X}}$ & Sd & Decision \\
\hline 6 & Classes of crops based on life span such as annual, biennials. & 3.42 & 0.71 & $\begin{array}{c}\text { Agree } \\
7\end{array}$ \\
7 & Uses of food crops such as cereal, tubers pulse, fruits, vegetables, oil, latex, & 3.25 & 0.82 & \\
& spices etc. & 3.43 & 0.68 & $*$ \\
8 & Sources of carbohydrate, protein, fats and oil, minerals and vitamins etc. & 3.25 & 0.91 & $*$ \\
9 & Use of farm animals based on size. & 3.50 & 0.77 & $*$ \\
10 & Use of farm animals based on habitat. & 3.25 & 0.77 & $*$ \\
11 & Uses of farm animals for food, labour sports, protection, clothing, source of & & & $*$ \\
& manure and hides and skin. & 3.60 & 0.82 & $*$ \\
12 & Simple farm tools such as Hoe, Cutlass etc. & 3.46 & 0.78 & $*$ \\
13 & Types of weeds, their control measures and their effects on the crops. & &
\end{tabular}

\section{Grand Mean $=3.39$}

Table 2 shows that all the items scored above the criterion level of 2.50, with the grand mean of 3.39 . This is an indication that the respondents agreed that indigenous language (Igbo) could be used to teach the process of agricultural production at the Junior Secondary Schools. Also the range of the standard deviations indicate that the opinions of the respondents did not deviate far from the central mean.

Research Question 3: How could the indigenous language be used in teaching of crop and animal diseases in agricultural production?

Table 3: Mean and Standard deviation of the respondents on the use of indigenous language in teaching of crop and animal diseases in agricultural production. $\mathrm{N}=276$.

\begin{tabular}{llccc}
\hline S/N & Items & $\overline{\boldsymbol{X}}$ & Sd & Decision \\
\hline 14 & Classification of crop pests such as piercing, sucking, chewing and biting & 3.21 & 0.86 & Agree \\
& insects & 3.33 & 0.75 & $*$ \\
15 & Damages done by the crop pest & 3.13 & 0.62 & $*$ \\
16 & Effects of crop pests on yield & 3.24 & 0.82 & $*$ \\
17 & Control of pests of crops & 3.13 & 0.78 & $*$ \\
18 & Classification of livestock pests such as, ecto parasite, endo parasite etc. & 3.39 & 0.72 & $*$ \\
19 & Damages done by the livestock pests to farm animals & 3.68 & 0.58 & $*$ \\
20 & Control measures of livestock pests. & & &
\end{tabular}

\section{Grand Mean}

Table 3 revealed that all the items had their mean scores above the cut-off point of 2.50 and the grand mean of 3.30, this signifies that the respondents were in agreement that indigenous language (Igbo) can be used to teach crop and animal diseases in agricultural production. This further indicated that the standard deviation of the responses did not deviate far from the central mean.

Research Question 4: How could the indigenous language be used in teaching of Agricultural business at the Junior Secondary Schools?

Table 4: Mean and Standard deviation of the Respondents on the use of indigenous language (Igbo) in teaching of Agricultural business.

\begin{tabular}{|c|c|c|c|c|}
\hline $\mathbf{S} / \mathbf{N}$ & Items & $\bar{X}$ & Sd & Decision \\
\hline 21 & Explanation of economic empowerment & 3.42 & 0.79 & Agree \\
\hline 22 & $\begin{array}{l}\text { Ways by which agriculture can empower someone economically such } \\
\text { as rearing of livestock, crop production etc. }\end{array}$ & 3.14 & 0.82 & \\
\hline 23 & Explanation of marketing of agricultural products & 3.08 & 0.80 & \\
\hline 24 & Importance of marketing of agricultural products & 3.27 & 0.80 & \\
\hline 25 & Different types of agricultural produce marketing & 3.48 & 0.69 & \\
\hline
\end{tabular}

\section{Grand Mean} $=$

3.27

Table 4 indicates that all the items had their mean scores above 2.50 which is the cut-off point, with the standard deviation ranging between 0.69 and 0.82 and the grand mean of 3.27. This indicates that the respondents agreed that the indigenous language (Igbo) could be used to teach agricultural business at the Junior Secondary Schools and the scores of the standard deviations indicate that the opinions of the respondents did not deviate far from the central mean. 
Table 5:Summary of t-test Analysis on the Responses of the Igbo and vocational agriculture teachers on the use of indigenous language in teaching of vocational agriculture at the Junior Secondary Schools.

\begin{tabular}{|c|c|c|c|c|c|c|c|c|c|}
\hline $\mathbf{S} / \mathbf{N}$ & Items & Group & $\mathbf{N}$ & $\overline{\boldsymbol{X}}$ & Sd & Df & t-cal. & t-tab & Interpretation \\
\hline & Basic Concepts of Agriculture & & & & & & & & \\
\hline 1 & Definition of Agriculture. & $\begin{array}{l}\text { Agric. Teacher } \\
\text { Igbo Teacher }\end{array}$ & $\begin{array}{l}136 \\
140\end{array}$ & $\begin{array}{l}3.27 \\
3.15 \\
\end{array}$ & $\begin{array}{ll}0.83 \\
1.03\end{array}$ & 274 & 1.05 & 1.96 & NSD \\
\hline 2 & Importance of Agriculture. & $\begin{array}{l}\text { Agric. Teacher } \\
\text { Igbo Teacher }\end{array}$ & $\begin{array}{l}136 \\
140 \\
\end{array}$ & $\begin{array}{l}3.31 \\
3.28 \\
\end{array}$ & $\begin{array}{l}0.83 \\
0.92\end{array}$ & 274 & 0.30 & 1.96 & NSD \\
\hline 3 & $\begin{array}{l}\text { Forms of agriculture such as crop, } \\
\text { farming, livestock farming, fishery } \\
\text { and so on. }\end{array}$ & $\begin{array}{l}\text { Agric. Teacher } \\
\text { Igbo Teacher }\end{array}$ & $\begin{array}{l}136 \\
140\end{array}$ & $\begin{array}{l}3.33 \\
3.07\end{array}$ & $\begin{array}{l}0.81 \\
0.83\end{array}$ & 274 & 2.60 & 1.96 & $\mathrm{SD}$ \\
\hline 4 & Different types of crops. & $\begin{array}{l}\text { Agric. Teacher } \\
\text { Igbo Teacher }\end{array}$ & $\begin{array}{l}136 \\
140 \\
\end{array}$ & $\begin{array}{l}3.19 \\
3.17\end{array}$ & $\begin{array}{l}0.81 \\
0.76\end{array}$ & 274 & 0.20 & 1.96 & NSD \\
\hline 5 & $\begin{array}{l}\text { Different types of farm animals such } \\
\text { as poultry, aquatic animals, work } \\
\text { animals, guard animals etc }\end{array}$ & $\begin{array}{l}\text { Agric. Teacher } \\
\text { Igbo Teacher }\end{array}$ & $\begin{array}{l}136 \\
140\end{array}$ & $\begin{array}{l}3.35 \\
3.14\end{array}$ & $\begin{array}{l}0.82 \\
0.82\end{array}$ & 274 & 2.10 & 1.96 & SD \\
\hline & Processes of Agric Production & & & & & & & & \\
\hline 6 & $\begin{array}{l}\text { Classes of crops based on life span } \\
\text { such as annual, biennials. }\end{array}$ & $\begin{array}{l}\text { Agric. Teacher } \\
\text { Igbo Teacher }\end{array}$ & $\begin{array}{l}136 \\
140 \\
\end{array}$ & $\begin{array}{l}3.61 \\
3.23 \\
\end{array}$ & $\begin{array}{l}0.74 \\
0.69 \\
\end{array}$ & 274 & 4.22 & 1.96 & SD \\
\hline 7 & $\begin{array}{l}\text { Uses of food crops such as cereal, } \\
\text { tubers pulse, fruits, vegetables, oil, } \\
\text { latex, spices etc. }\end{array}$ & $\begin{array}{l}\text { Agric. Teacher } \\
\text { Igbo Teacher }\end{array}$ & $\begin{array}{l}136 \\
140\end{array}$ & $\begin{array}{l}3.33 \\
3.77\end{array}$ & $\begin{array}{l}0.84 \\
0.81\end{array}$ & 274 & 1.60 & 1.96 & NSD \\
\hline 8 & $\begin{array}{l}\text { Sources of carbohydrate, protein, fats } \\
\text { and oil, minerals and vitamins etc. }\end{array}$ & $\begin{array}{l}\text { Agric. Teacher } \\
\text { Igbo Teacher }\end{array}$ & $\begin{array}{l}136 \\
140 \\
\end{array}$ & $\begin{array}{l}3.62 \\
3.25 \\
\end{array}$ & $\begin{array}{l}0.72 \\
0.65 \\
\end{array}$ & 274 & 4.11 & 1.96 & SD \\
\hline 9. & Use of farm animals based on size. & $\begin{array}{l}\text { Agric. Teacher } \\
\text { Igbo Teacher }\end{array}$ & $\begin{array}{l}136 \\
140\end{array}$ & $\begin{array}{l}3.41 \\
3.09 \\
\end{array}$ & $\begin{array}{l}0.83 \\
1.00\end{array}$ & 274 & 2.90 & 1.96 & $\mathrm{SD}$ \\
\hline 10 & Use of farm animals based on habitat. & $\begin{array}{l}\text { Agric. Teacher } \\
\text { Igbo Teacher }\end{array}$ & $\begin{array}{l}136 \\
140 \\
\end{array}$ & $\begin{array}{l}3.69 \\
3.32 \\
\end{array}$ & $\begin{array}{l}0.70 \\
0.83\end{array}$ & 274 & 3.70 & 1.96 & SD \\
\hline 11 & $\begin{array}{l}\text { Uses of farm animals for food, labour } \\
\text { sports, protection, clothing, source of } \\
\text { manure and hides and skin. }\end{array}$ & $\begin{array}{l}\text { Agric. Teacher } \\
\text { Igbo Teacher }\end{array}$ & $\begin{array}{l}136 \\
140\end{array}$ & $\begin{array}{l}3.33 \\
3.18\end{array}$ & $\begin{array}{l}0.85 \\
0.70\end{array}$ & 274 & 1.50 & 1.96 & NSD \\
\hline 12 & $\begin{array}{l}\text { Simple farm tools such as Hoe, } \\
\text { Cutlass etc. }\end{array}$ & $\begin{array}{l}\text { Agric. Teacher } \\
\text { Igbo Teacher }\end{array}$ & $\begin{array}{l}136 \\
140 \\
\end{array}$ & $\begin{array}{l}3.66 \\
3.54\end{array}$ & $\begin{array}{l}0.76 \\
0.89\end{array}$ & 274 & 1.20 & 1.96 & NSD \\
\hline 13 & $\begin{array}{l}\text { Types of weeds their control } \\
\text { measures and their effects on the } \\
\text { crop. }\end{array}$ & $\begin{array}{l}\text { Agric. Teacher } \\
\text { Igbo Teacher }\end{array}$ & $\begin{array}{l}136 \\
140\end{array}$ & $\begin{array}{l}3.38 \\
3.55\end{array}$ & $\begin{array}{l}0.71 \\
0.85\end{array}$ & 274 & -1.70 & 1.96 & NSD \\
\hline & Crop \& Animal Diseases & & & & & & & & \\
\hline 14 & $\begin{array}{l}\text { Classification of crop pests such as } \\
\text { piercing, sucking, chewing and biting } \\
\text { insects }\end{array}$ & $\begin{array}{l}\text { Agric. Teacher } \\
\text { Igbo Teacher }\end{array}$ & $\begin{array}{l}136 \\
140\end{array}$ & $\begin{array}{l}3.17 \\
3.25\end{array}$ & $\begin{array}{l}0.80 \\
0.92\end{array}$ & 274 & -0.80 & 1.96 & NSD \\
\hline 15 & Damages done by the crop pest & $\begin{array}{l}\text { Agric. Teacher } \\
\text { Igbo Teacher }\end{array}$ & $\begin{array}{l}136 \\
140\end{array}$ & $\begin{array}{l}3.22 \\
3.45\end{array}$ & $\begin{array}{l}0.78 \\
0.73\end{array}$ & 274 & 0.70 & 1.96 & NSD \\
\hline 16 & Effects of crop pests on yield & $\begin{array}{l}\text { Agric. Teacher } \\
\text { Igbo Teacher }\end{array}$ & $\begin{array}{l}136 \\
140 \\
\end{array}$ & $\begin{array}{l}3.38 \\
2.88 \\
\end{array}$ & $\begin{array}{l}0.62 \\
0.62\end{array}$ & 274 & -6.25 & 1.96 & NSD \\
\hline 17 & Control of pests of crops & $\begin{array}{l}\text { Agric. Teacher } \\
\text { Igbo Teacher }\end{array}$ & $\begin{array}{l}136 \\
140 \\
\end{array}$ & $\begin{array}{l}3.16 \\
3.32 \\
\end{array}$ & $\begin{array}{l}0.80 \\
0.84 \\
\end{array}$ & 274 & -0.80 & 1.96 & NSD \\
\hline 18 & $\begin{array}{l}\text { Classification of livestock pests such } \\
\text { as, ecto parasite, endo parasite etc. }\end{array}$ & $\begin{array}{l}\text { Agric. Teacher } \\
\text { Igbo Teacher }\end{array}$ & $\begin{array}{l}136 \\
140 \\
\end{array}$ & $\begin{array}{l}3.20 \\
3.07 \\
\end{array}$ & $\begin{array}{l}0.79 \\
0.78 \\
\end{array}$ & 274 & 1.30 & 1.96 & NSD \\
\hline 19 & $\begin{array}{l}\text { Damages done by the livestock pests } \\
\text { to farm animals }\end{array}$ & $\begin{array}{l}\text { Agric. Teacher } \\
\text { Igbo Teacher }\end{array}$ & $\begin{array}{l}136 \\
140 \\
\end{array}$ & $\begin{array}{l}3.33 \\
3.45 \\
\end{array}$ & $\begin{array}{l}0.68 \\
0.79\end{array}$ & 274 & -1.20 & 1.96 & NSD \\
\hline 20 & Control measures of livestock pests. & $\begin{array}{l}\text { Agric. Teacher } \\
\text { Igbo Teacher }\end{array}$ & $\begin{array}{l}136 \\
140 \\
\end{array}$ & $\begin{array}{l}3.50 \\
3.87 \\
\end{array}$ & $\begin{array}{l}0.68 \\
0.48 \\
\end{array}$ & 274 & -4.62 & 1.96 & NSD \\
\hline & Agric Business & & & & & & & & \\
\hline 21 & $\begin{array}{lll}\begin{array}{l}\text { Explanation } \\
\text { empowerment }\end{array} & \text { of economic } \\
\end{array}$ & $\begin{array}{l}\text { Agric. Teacher } \\
\text { Igbo Teacher }\end{array}$ & $\begin{array}{l}136 \\
140 \\
\end{array}$ & $\begin{array}{l}3.44 \\
3.40 \\
\end{array}$ & $\begin{array}{l}0.74 \\
0.85 \\
\end{array}$ & 274 & 0.40 & 1.96 & NSD \\
\hline 22 & $\begin{array}{l}\text { Ways by which agriculture can } \\
\text { empower someone economically } \\
\text { such as rearing of livestock, crop } \\
\text { production etc. }\end{array}$ & $\begin{array}{l}\text { Agric. Teacher } \\
\text { Igbo Teacher }\end{array}$ & $\begin{array}{l}136 \\
140\end{array}$ & $\begin{array}{l}3.19 \\
3.10\end{array}$ & 0.79 & 274 & 0.90 & 1.96 & NSD \\
\hline 23 & $\begin{array}{l}\text { Explanation of marketing of } \\
\text { agricultural products }\end{array}$ & $\begin{array}{l}\text { Agric. Teacher } \\
\text { Igbo Teacher }\end{array}$ & $\begin{array}{l}136 \\
140 \\
\end{array}$ & $\begin{array}{l}3.11 \\
3.05 \\
\end{array}$ & $\begin{array}{l}0.81 \\
0.79 \\
\end{array}$ & 274 & 0.60 & 1.96 & NSD \\
\hline 24 & $\begin{array}{l}\text { Importance of marketing of } \\
\text { agricultural products }\end{array}$ & $\begin{array}{l}\text { Agric. Teacher } \\
\text { Igbo Teacher }\end{array}$ & $\begin{array}{l}136 \\
140\end{array}$ & $\begin{array}{l}3.13 \\
3.42\end{array}$ & $\begin{array}{l}0.82 \\
0.79\end{array}$ & 274 & -2.90 & 1.96 & NSD \\
\hline 25 & $\begin{array}{l}\text { Different types of agricultural } \\
\text { produce marketing }\end{array}$ & $\begin{array}{l}\text { Agric. Teacher } \\
\text { Igbo Teacher }\end{array}$ & $\begin{array}{l}136 \\
140 \\
\end{array}$ & $\begin{array}{l}3.46 \\
3.50 \\
\end{array}$ & $\begin{array}{l}0.61 \\
0.78\end{array}$ & 274 & -0.44 & 1.96 & NSD \\
\hline
\end{tabular}

\section{Key: NSD = Not Significant different; SD $=$ Significant different}

Table 5 revealed that all the 25 items except items 3,5,6,8,9 and 10 had their t-calculated less than the t-table of 1.96. Based on this, the null-hypothesis was accepted in all the items meaning that there was no significant difference in the mean responses of the vocational agricultural and Igbo teachers on the use of indigenous language in teaching of vocational agriculture at the Junior Secondary Schools in Ebonyi State of Nigeria. 
Discussion of Findings

The results of data analysis in tables 1,2,3 and 4 revealed that indigenous language (Igbo) could be used to teach the basic concepts of agriculture, the processes of agricultural production, crops and animal diseases in agricultural production and agricultural business at the Junior Secondary Schools. This agree with views of Ugbo (2004) and Onyemenam (2006) who assert that the use of indigenous language in teaching students can influence the effective learning of agriculture, enhance their understanding of agricultural technologies and improve the teaching and learning of agriculture for a better understanding and improvement of the totality of the farming operations.

The study also revealed that there was no significant difference in the mean responses of the Igbo language and vocational agriculture teachers on the use of indigenous language (Igbo) in the teaching of vocational agriculture at the Junior Secondary Schools. Therefore, it means that there is a general consensus among the vocational agriculture and the Igbo teachers that Igbo language can be effectively utilized in the instruction of vocational agriculture at the Junior Secondary Schools.

\section{Conclusion}

It has already been established by the findings of this study that indigenous language (Igbo) could be used to teach basic concepts of agriculture, the processes of agricultural production, crops and animal disease in agricultural production, and agricultural business at the Junior Secondary Schools. It is the researchers' opinions therefore that vocational agriculture teachers should employ the use of indigenous language for improving the teaching of agriculture at the JSS level as this will enhance the learning of agricultural practices, which will invariably boost agricultural production and reduce food scarcity in the society.

\section{Recommendations}

Based on the findings of this study, the researchers made the following recommendations:

1. That vocational agriculture teachers should use indigenous language (Igbo) in teaching and learning of vocational agriculture at the Junior Secondary School level.

2. That government, curriculum planners and all the authorities concerned in Junior Secondary School administrations should ensure that teachers' handbook, manuals in vocational agriculture are translated in Igbo language for effective teaching and learning.

\section{Acknowledgments:}

The researchers wish to acknowledge the staff of Ebonyi State Universal Basic Education Board for supplying some of the information used in this work. Also the researchers' appreciation goes to the data analysis for the analysis of the data.

\section{References}

Akande, M. O. (2004). Fundamentals of Pedagogy and General Principles of Education. Ikoyi Printing Press Ltd, Mushin, Lagos.

Bamgbose, A. (1984). Mother - tongue Medium and Scholastic attainment in Nigeria. In prospects UNESCO 1984

Blench, R. (2012). An atlas of Nigerian Languages $\left(3^{\text {rd }}\right.$ ed). Cambridge, UK. Kay Williamson Educational Foundation.

Collier, V. P., \& Thomas, W. P. (2004). The astounding effectiveness of dual language education for all. NABE. Journal of Research and Practice, 2 (1), $1-20$

Federal Republic of Nigeria (2007). Official Gazette, 24 (94) Lagos $15^{\text {th }}$ May

Federal Republic of Nigeria (1998; 2014). National Policy on Education. NERDC Press, Lagos.

Garcia, E. E. (2005). Teaching and Learning in two languages:Bilingual \& Schooling in the United States Teachers' College Press.

Ndem, J. (2016). Mechanisms for enhancing teacher's effectiveness in the implementation of agricultural science programme in Secondary Schools in Afikpo Education Zone, Ebonyi State. Journal of Association of Vocational Educators of Nigeria 21(2) 66 - 72.

Ohiri-Anihe, C. (2014). Local languages for Global Citizenship: Spotlight on Science. The Vanguard.

Owolabi, T. \&Makinde, S. O. (2008). Localizing Science Teaching in indigenous language: Yoruba Language experience. Journal of Nigerian Language and Culture. APNILAC 1(10), 229 - 238.

Onyemenam, O. (2004). The Nigerian Languages and the teaching of English Language, London Longman.

Ugbo, O. (2004). Benefits of indigenous language in the teaching and learning of Adult Farmers in Delta State. Journal of Agriculture and Social Research. 4(2). 2004.

United Nations Education, Scientific, and Cultural Organization (1974). Recommendation Concerning Education for international understanding, cooperation and peace and education relating to Human Rights and Foundational Freedom.UNESCO Manual. 